\title{
ACCULTURATION STRATEGIES AND PERCEPTION OF A NORTH AFRICAN WOMAN IN A JUDICIAL CONTEXT
}

\author{
Chloé Dougez ${ }^{1}$, Anne Taillandier-Schmitt ${ }^{1,2}, \&$ Nicolas Combalbert ${ }^{1}$ \\ ${ }^{1}$ Université de TOURS (France) \\ ${ }^{2}$ Université Rennes 2 (France)
}

\begin{abstract}
This study examines some extrajudicial factors that may influence the judgment of a woman from North African immigration. The perception of women with North African origin in our society is a poorly researched subject in psychology whereas they are the target of many stereotypes. In this study, we have been interested in the judgments of men and women on a North African woman who committed an assault on another woman (with a French-sounding name). We particularly studied the effects of acculturation strategies adopted by the perpetrator (adoption of the culture of the host country/retention of the original culture) and the profile of the participant (gender and social dominance orientation, SDO. Two hundred and eighty-six students read a scenario describing an assault committed by a North African woman who was then described according to one of the four acculturation strategies (assimilation, integration, separation, and marginalization) in many areas of daily life (work, family, social life...). The consequences of the assault for the victim were also manipulated (serious or minimal). After reading the scenario, participants judged the act and its perpetrator in four dimensions: judgment of the act, behavior explanation, and judgment of the perpetrator, perception of her masculine and feminine traits. Our results suggested that when the perpetrator did not adopt French culture and/or she maintained her original culture, participants judged her more negatively than in the other conditions and her behaviour was explained more by internal factors than external factors. These results were particularly observed for participants with high level of SDO. Otherwise, depending on the conditions of the experimentation, the judgments of women and men were different. The results of this study were discussed in view of stereotypical norms and threat feeling.
\end{abstract}

Keywords: Acculturation strategies, North African origin, gender, judgements, women delinquency.

\section{Introduction}

This study examines three extrajudicial factors that may influence the judgment of a woman from North African immigration. The perception of women with North African origin in our society is a poorly researched subject in psychology whereas they are the target of many stereotypes (Boukhobza, 2005; Beski 2011). Some studies highlight that people with an immigrant background are judged by the host population differently depending on the way they fit in the culture of the host country (Maisonneuve \& Testé, 2007; Maisonneuve, Testé, Taillandier-Schmitt, \& Dambrun, 2014). Furthermore, two studies have shown that a man or a woman with North African origin is judged more negatively and more severely if they do not adopt the French culture or they maintain their original culture, in a judicial context (Dougez, Taillandier-Schmitt, 2018; Taillandier-Schmitt and Combalbert, 2017). In this study, we are interested in the difference of judgments depending on the gender of the participant at the look of the status of the North African woman. Indeed, women of North African origin have long been absent from the social scene and are portrayed in the media in controversial contexts, such as wearing headscarves or burkinis (Gourdeau, 2015). These polemical issues confirm the stereotypes of women from North Africa, who are often considered as oppressed and subject to male authority. In this case, a North African woman who commits an assault transgresses several stereotypes. As described above, the transgression of stereotyped norms gives rise to harsh judgments (Delacolette, Dardenne, \& Dumond, 2010), especially if the person is likely to undermine a dominant position (for instance, for men when a woman has masculine characteristics). In this study, the perpetrator is described according one of the four acculturation strategies described by Berry (2005) on the bi-dimensional model, which may influence the perception of her and its behavior. Our questions are focused on the influence and interactions of the effects of gender and acculturation strategies on the judgement on a North African woman. We have included a measure of 
level of SDO (Pratto, Sidanius, Stallworth, \& Malle, 1994) because it may influence the judgment in judicial context (Fosterlee, Horowitz, Fosterlee, King \& Ronlund, 1999) and related to acculturation strategies (Levin \& al., 2012).

\section{Objectives}

The purpose of this study was to examine the effects and the interaction of the acculturation strategy adopted by a North African woman who committed an assault with the profile of participants who judged her. Women with North African origin are the target of some gender stereotypes so we decided to observe the gender variable and participants' level of SDO.

\section{Hypotheses}

We hypothesized that the target will be judged less negatively by participants when she adopts the French culture and if she does not maintain exclusively her original culture. We also hypothesized that men will judge more negatively the target depending on the condition of the experimentation (serious consequences and no retention of the original culture).

\section{Method}

Two hundred and eighty-six students (140 men and 146 women) aged 18 to 39 ( $M=20.962$, $S D=2.756$ ) participated in the study. They had different academic backgrounds. They read a scenario describing an assault committed by a North African woman (named "Jamila") against another woman (with a French-sounding name, "Valérie"). The consequences of the assault for the victim were also manipulated: either the victim managed to get away (minimal consequences) or she was knocked unconscious (serious consequences). A description then identifies whether or not she adopts the French culture and/or whether or not she maintains her original culture; depending on the bi-dimensional model of Berry (2005) : 1) she has adopted French culture and rejected her original culture (assimilation), 2) she has adopted French culture and maintained her original culture (integration), 3) she has rejected French culture and maintained her original culture (separation), 4) she has not adopted French culture or conserved her original culture (marginalization). After reading the scenario and the description, participants judged the act and its perpetrator in four dimensions: judgment of the act, behavior explanation, and judgement of the perpetrator, perception of her masculine and feminine traits. The level of SDO was also examined (Pratto, Sidanius, Stallworth, \& Malle, 1994).

\section{Results}

Our results may partly answer to our hypotheses in that we have observed the effects of the adoption of the culture of the country and retention of the original culture, and differences in judgments between women and men, related to the acculturation strategy of the perpetrator and participant's level of SDO. We observe an influence of acculturation strategies on three variables: aggravating circumstances, risk of recidivism and masculine traits (Table 1). Then the results show a main effect of the gender on the measures of level of SDO, custodial sentence, mitigating circumstances and threatening (Figure 1). And we found an effect of participant's level of SDO on the measures of custodial sentence, general impression, and risk of recidivism and attribution of feminine traits (Figure 2). Depending on the seriousness of the consequences for the victim, the adoption of the French culture and the retention of the original culture have influenced participants' judgment : our analyses revealed that when the consequences of the act were serious, the participants attributed the act more to the situation when the perpetrator adopted an integration strategy (adoption and retention) $(M=-.351, S D=2.176)$ than when she adopted a separation strategy (no adoption and retention) $(M=1.211, S D=2.622, p=.008)$. By contrast, the participants attributed the behavior more to personal factors when the consequences were minimal and the perpetrator adopted either an integration strategy (adoption and retention) $(M=1.108$, $S D=2.283, p=.01)$ or an assimilation strategy (adoption and no retention) $(M=.811, S D=2.196$, $p=.04)$. Then, men considered generally the North African woman as more threatening than students women $\left(F(1,254)=4.730, p=.03, \eta^{2}=.02\right)$, even more so if the consequences for the victim are serious $\left(F(1,254)=6.257, p=.01, \eta^{2}=.02\right)$. If the perpetrator does not adopt the French culture, men attributed more aggravating circumstances to her than women $\left(F(1,254)=5.301, p=.02, \eta^{2}=.02\right)$. Furthermore, the higher level of SDO predicted a more negative judgment of the perpetrator, and the judgment of women seems to be more depending on their level of SDO than men although that of men is generally higher than that of women. Finally, we observed effects of gender, acculturation strategy and level of SDO of the attribution of masculine and feminine traits to the perpetrator. 


\section{Discussion}

We discuss these results in view of stereotypical norms (Delacolette, Dardenne, \& Dumond, 2010) and threat feeling. In this study, the perpetrator transgresses several stereotypes and the participants judgments may be influenced by their perception of the level of the transgression, which is different depending on the gender, the level of SDO or the acculturation strategy of the perpetrator. Furthermore, depending on the condition of this experimentation and the profile of the participant, the threatening perception of the perpetrator may influence judgements. Men may have felt threatened by the perpetrator because in our study she does not correspond to the female stereotype and adopts male characteristics (violence). We can also interpret the results of this study in terms of adherence to stereotypes, which is consistent with the idea that men have a higher level of SDO than women: the more a person adheres to the stereotypes, the more he will judge negatively a perpetrator who transgresses stereotypes.

\section{Conclusion}

The study of the perception of North African women is a little explored subject in psychology, whereas they are the target of several stereotypes and they can experiment it, especially in the field of employment (Meurs \& Pailhé, 2010). This study is part of a desire to understand social dynamics related to the interaction between gender stereotypes and acculturation phenomena. In the judicial context, it is particularly important to focus on it as perceptions of women and migrants are discussed in the social scene.

Table 1. Means and standard deviations of measures related to retention of the original culture and adoption of French culture.

\begin{tabular}{ccccc} 
& \multicolumn{2}{c}{ Adoption } & \multicolumn{2}{c}{ No adoption } \\
& $\begin{array}{c}\text { Retention } \\
\text { (integration) }\end{array}$ & $\begin{array}{c}\text { No retention } \\
\text { (assimilation) }\end{array}$ & $\begin{array}{c}\text { Retention } \\
\text { (separation) }\end{array}$ & $\begin{array}{c}\text { No retention } \\
\text { (marginalization) }\end{array}$ \\
\hline $\begin{array}{c}\text { Aggravating } \\
\text { circumstances }\end{array}$ & $2.635(1.61)$ & $3.200(1.682)$ & $3.147(1.95)$ & $2.597(1.86)$ \\
Risk of recidivism & $3.649(1.557)$ & $3.486(1.759)$ & $4.587(1.779)$ & $3.97(1.696)$ \\
Masculine traits & $5.088(1.077)$ & $5.021(1.352)$ & $5.607(1.098)$ & $4.754(1.369)$
\end{tabular}

Figure 1. Main effect of the gender on the measures of level of SDO, custodial sentence, mitigating circumstances and threatening.

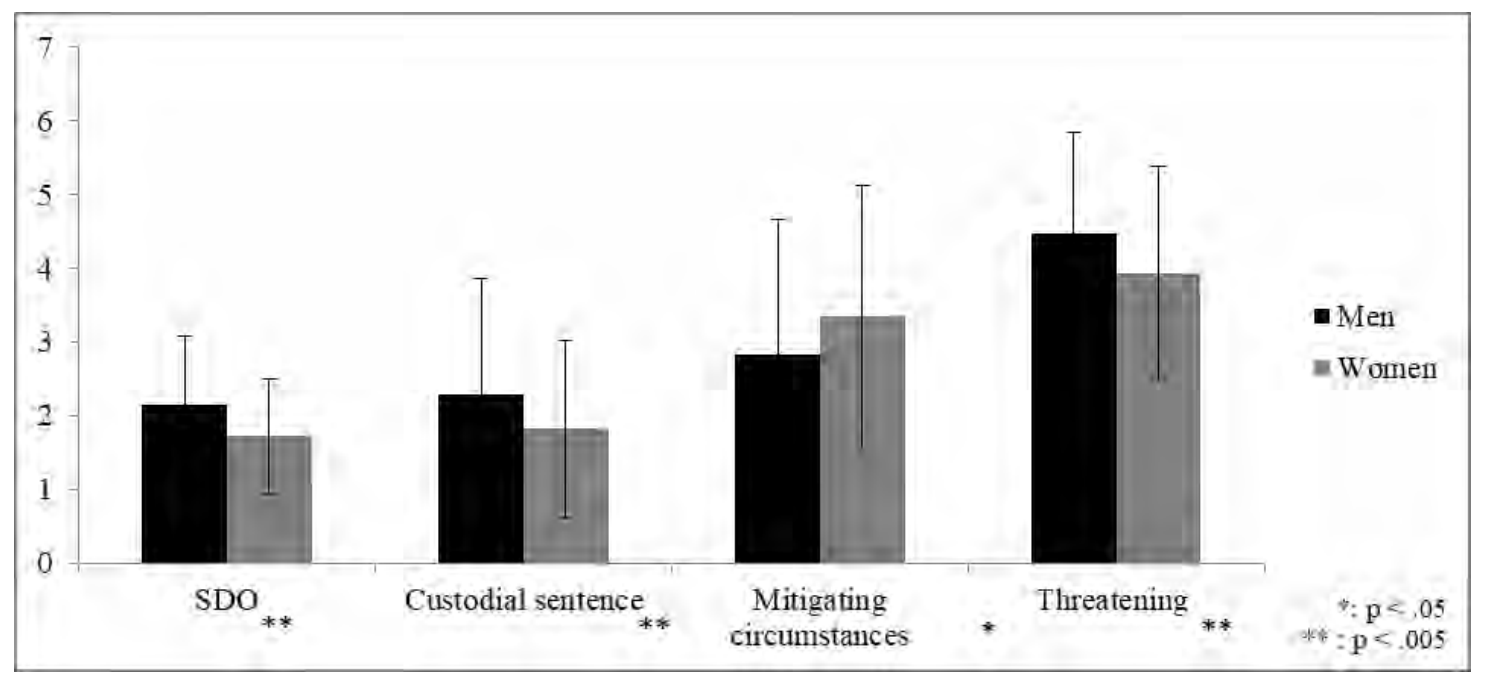


Figure 2. Effect of participant's level of SDO on the measures of custodial sentence, general impression, risk of recidivism and attribution of feminine traits.

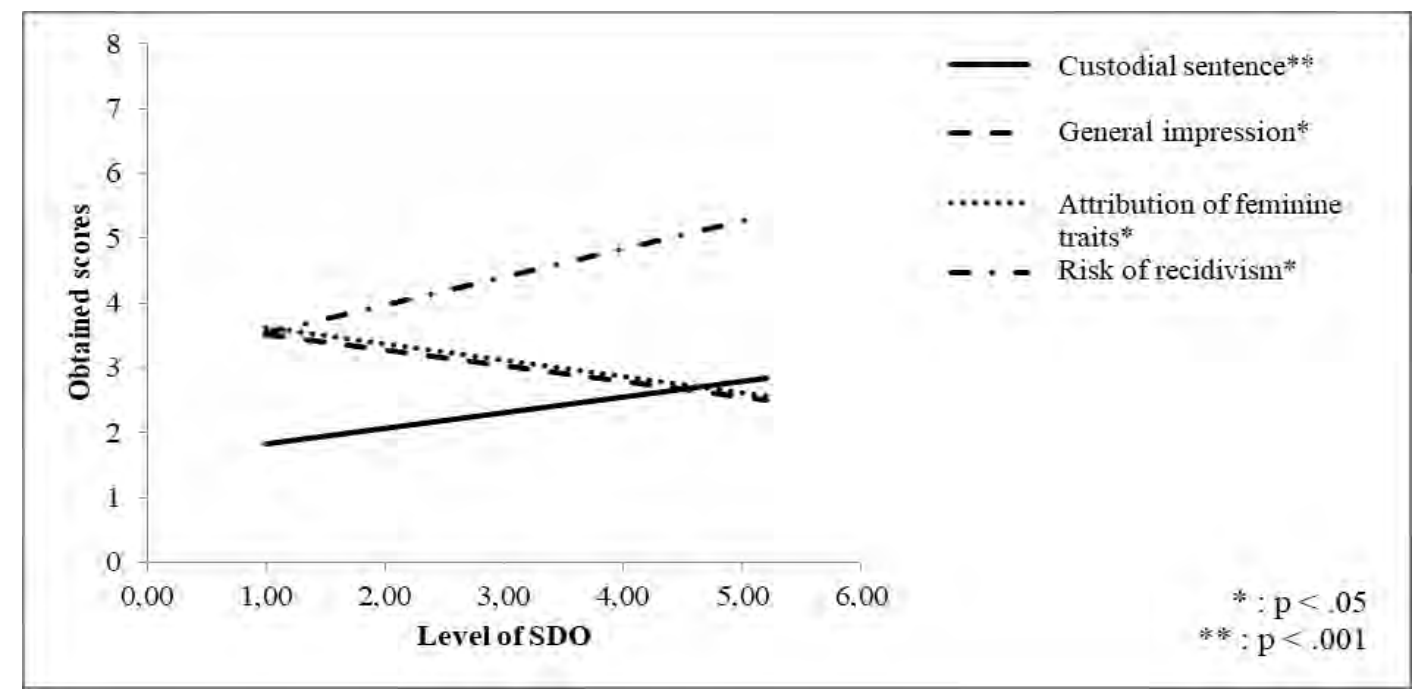

\section{References}

Berry, J. W. (2005). Acculturation: Living successfully in two cultures. International Journal of Intercultural Relations, 29(6), 679-712. doi: 10.1016/j.ijintrel.2005.07.013

Beski, C. (2011). Femmes issues de l'immigration: L'urgence d'une approche complexe. Ville école intégration, 13, 37-41. Retrived from https://www.adric.eu/index.php/nos-publications/66publications/152-chahka-beski-femmes-issues-des-immigrations-lurgence-dune-approchecomplexe

Boukhobza, N. (2005). Les filles naissent après les garçons. Revue Européenne des Migrations Internationales, 21(1), 227-242. Retrieved from http://remi.revues.org/2333

Delacolette, N., Dardenne, B. \& Dumont, M. (2010). Stéréotypes prescriptifs et avantages des groupes dominants. L'année psychologique, 110, 127-156.doi: 10.4074/S0003503310001053

Dougez, C., Taillandier-Schmitt, A., and Combalbert, N. (2018). Influence of acculturation strategies on the judgement of violent act committed by a North African woman. International review of social psychology, 31(1). doi: 10.5334/irps.106

Fosterlee, L., Horowitz, I. A., Fosterlee, R., King, K., \& Ronlund L. (1999). Death penalty attitudes and juror decisions in Australia. Australian Psychologist, 24, 64-69. doi.: 10.1080/00050069908257427

Gourdeau, C. (2015). Une politique d'intégration au service des femmes étrangères? Hommes et Migrations, 1311, 23-29. Retrieved from https://www.cairn.info/revue-hommes-et-migrations2015-3-page-23.htm

Levin, S., Matthews, M., Guimond, S., Sidanius, J., Pratto, F., Kteily, N., Pitpitan, E.V., \& Dover, T. (2012). Assimilation, multiculturalim, and colorblindness: Mediated and moderated relationschips between social dominance orientation and prejudice. Journal of Experimental Psychology, 48(1), 207-212. doi: 10.1016/j.jesp.2011.06.019

Maisonneuve, C., \& Testé, B. (2007). Acculturation preferences of host community: The effect of immigrants acculturation strategies on evaluation and impression formation. International Journal of Intercultural Relation, 31, 669-688. doi: 10.1016/j.ijintrel.2007.06.001

Maisonneuve, C., Testé, B., Taillandier-Schmitt, A., \& Dambrun, M. (2014). Host populations' perceptions toward migrants: The effect of private/public settings and the moderating role of threat. International Journal of Intercultural Relations, 41, 45-56. doi: 10.1016/j.ijintrel.2014.05.006

Meurs, D., \& Pailhé, A. (2010). Position sur le marché du travail des descendants directs d'immigrés en France: les femmes doublement désavantagées? Economie et Statistique, 431-432, 129-151. doi: 10.3406/estat.2010.8078

Pratto, F., Sidanius, J., Stallworth, L. M., \& Malle, B. F. (1994). Social dominance orientation: A personality variable predicting social and political attitudes. Journal of Personality and Social Psychology, 67, 741-763. doi: 10.1037/0022-3514.67.4.741

Taillandier-Schmitt, A., and Combalbert, N. (2017). Influence of acculturation strategies on the judgement and punishment of an offender of North African descent. Psychology, Crime \& Low, 23(9). doi: 10.1080/1068316X.2017.1335731 